\title{
The Mechanism of Action for the Block of NMDA Receptor Channels by the Opioid Peptide Dynorphin
}

\author{
Li Chen, Yanping Gu, and Li-Yen Mae Huang
}

Marine Biomedical Institute and Department of Physiology and Biophysics, University of Texas Medical Branch, Galveston, Texas 77555-1069

\begin{abstract}
Dynorphin is one of the endogenous opioids that modulates the excitability of nociceptive (pain-sensing) neurons. We have shown recently that dynorphin blocks NMDAactivated currents directly without the participation of «-opioid receptors. In order to understand the mechanism underlying this novel action of dynorphin, we examined, in detail, the interactions between dynorphin and NMDA receptors in isolated trigeminal neurons. Dynorphin reversibly blocks NMDA-activated current $\left(I_{\mathrm{NMDA}}\right)$. The onset and recovery of the block were determined with concentration jump experiments. The association rate $\left(k_{+}\right)$of dynorphin(1-17) is $4.9 \times 10^{6} \mathrm{sec}^{-1} \mathrm{~m}^{-1}$ and the dissociation rate $\left(k_{-}\right)$is $7.5 \mathrm{sec}^{-1}$. The apparent dissociation constant $\left(K_{D}\right)$ of dynorphin, calculated from these rate constants, is $1.6 \mu \mathrm{M}$. Dynorphin does not change the $\mathrm{EC}_{50}$ of NMDA, nor the potentiating action of glycine. The binding site for dynorphin is distinct from that of $\mathrm{Zn}^{2+}$ or $\mathrm{H}^{+}$. Upon treatment with the disulfide reducing agent dithiothreitol (DTT), NMDA receptors become less susceptible to dynorphin block. The affinity of dynorphin for the modified NMDA receptors is reduced by 2.7-fold. In analyses of single NMDA channels in cell-free patches, we found that dynorphin shortens the mean open time, decreases the probability of opening of NMDA channels, but has no effect on the single channel conductance. These results suggest that dynorphin interacts with a site conformationally linked with the redox site(s) on the NMDA receptor, thus altering the gating properties of the channel.
\end{abstract}

[Key words: dynorphin, trigeminal neurons, pain, NMDA receptor channel, nonopioid, $\kappa$-opioid]

Trigeminal and spinal dorsal horn neurons in the spinothalamic tract (STT) relay nociceptive and temperature information to the brain. These neurons receive noxious inputs from primary afferent fibers, integrate modulatory influences from descending and local circuits and send the information to the thalamus and the somatosensory cortex (Zieglgansberger, 1986; Fields, 1987; Willis and Coggeshall, 1991). The major excitatory transmitters mediating the synaptic transmission in this nociceptive pathway are glutamate and aspartate. They are located in afferent fibers,

Received Oct. 24, 1994; revised Jan. 19, 1995; accepted Jan. 24, 1995

We thank K. Forni for technical assistance and preparation of the manuscript and S. Y. Wong for cell preparation. The work is supported by NIH Grants NS30045, NS23061, and NS1 1255 to L.-Y.M.H.

Correspondence should be addressed to Dr. Li-Yen Mae Huang, Marine Biomedical Institute, University of Texas Medical Branch, Galveston, TX 775.55. 1069

Copyright (C) 1995 Society for Neuroscience $\quad 0270-6474 / 95 / 154602-10 \$ 05.00 / 0$ interneurons (Schneider and Perl, 1985; Battaglia and Rustioni, 1988; Schneider and Perl, 1988), and in 50\% of the terminals apposing the somata and dendrites of the projection neurons (Westlund et al., 1992). In response to noxious stimuli, glutamate and aspartate are released (Potashner and Tran, 1984; Skilling et al., 1988) and activate NMDA and non-NMDA receptors (Jahr and Jessell, 1985; Aanonsen and Wilcox, 1987; Gerber and Randić, 1989; Gu and Huang, 1989; Gu and Huang, 1990; Yoshimura and Jessell, 1990; Chen and Huang, 1992a; Dougherty and Willis, 1992; Dougherty et al., 1992).

The endogenous opioid, dynorphin, has been shown to contribute to analgesia under physiological conditions (Millan, 1990). Immunolabeled dynorphin cells are concentrated in laminae I and II of the dorsal horn. Some can be seen in deeper laminae (IV-VI and X) (Cruz and Basbaum, 1985; Miller and Seybold, 1987; Ruda et al., 1988; Weihe et al., 1989). Kappa $(\kappa)$-receptor binding is found mostly in lamina II (Gouarderes et al., 1985; Morris and Herz, 1987). There is considerable mismatch between the anatomical distribution of dynorphin and the $\kappa$-receptor binding, similar to those of $\mu$ - and $\delta$-opioid peptides (Mansour et al., 1988; Mansour and Watson, 1993).

Responding to high frequency stimulation of unmyelinated afferent fibers, dynorphin(1-17), a primary product of prodynorphin (Cone et al., 1983), is released in laminae I and V-VI (Hutchison et al., 1990) and can modulate synaptic transmission in the dorsal horn. Dynorphin and the $\mathrm{k}$-opioid agonist $\mathrm{U} 50,488 \mathrm{H}$ were found to reduce the firing frequency of dorsal horn neurons evoked by glutamate application (Willcockson et al., 1986), by electrical C-fiber stimulation (Knox and Dickenson, 1987; Caudle and Isaac, 1988), or by noxious mechanical and thermal stimuli (Fleetwood-Walker et al., 1988; Millan, 1989; Hope et al., 1990). Behavioral studies have shown that intrathecal administration of dynorphin(1-17) increases the latency of thermally evoked tail flick reflexes (Herman and Goldstein, 1985; Spampinato and Candeletti, 1985) (for review, see Yaksh, 1993). In addition to the inhibitory effects, dynorphin sometimes exerts excitatory actions on these neurons. Application of dynorphin was found to increase the receptive field, to enhance the activity of dorsal horn neurons in response to C-fiber or mechanical stimulation (Knox and Dickenson, 1987; Hylden et al., 1991) and to enhance the glutamate-evoked firing of STT neurons (Willcockson et al., 1986). Not all of these dynorphin actions are mediated by к-opioid receptors; many of the dynorphin effects can not be blocked by high doses of the opioid receptor antagonist naloxone (Willcockson et al., 1986; Knox and Dickenson, 1987; Caudle and Isaac, 1988; Hylden et al., 1991). 
Dynorphin and NMDA receptors are thought to play a pivolal role in the sensitization of nociceptive neurons (Dubner and Ruda, 1992). Upon receiving repetitive stimuli to small diameter afferent fibers, the dorsal horn neurons generate prolonged depolarization and/or fire with increasing frequency, that is, "windup" (Wall and Woolf, 1984; Dickenson and Sullivan, 1987; Yoshimura and Jessel, 1989). This sensitization of central neurons can not be initiated nor be maintained when the activation of NMDA receptors is blocked by $( \pm)$-2-amino-5-phosphonovalcric acid (APV) (Davies and Lodge, 1987; Dickenson and Sullivan, 1987; Headley et al., 1987; Woolf and Thompson, 1991). Following tissue injury or inflammation, dorsal horn neurons develop hypersensitivity to innocuous or noxious stimuli and the receptive ficld size for these neurons increases (Hylden et al., 1991). In addition to the change in electrical activity, the cxpression of opioids is also enhanced after tissue injury. Enkephalin increases about $50 \%$; dynorphin increases up to fourfold (Millan et al., 1986; Iadarola et al., 1988; Weihe et al., 1989; Kajander et a1., 1990; Dubner and Ruda, 1992; Millan, 1993). The consequence of this large increase in dynorphin expression is not clear at the moment.

The cellular mechanisms of dynorphin actions have been studied extensively (Huang, 1995). Presynaptically, dynorphin changes the release of glutamate, noradrenaline, SP, and enkephalin (Werling et al., 1987; Xu and Gintzler, 1989; Gannon and Terrian, 1991; Suarez Roca and Maixner, 1993; Wagner et al., 1993; Weisskopf et al., 1993). Postsynaptically, dynorphin hyperpolarizes the membrane by opening $\mathrm{K}^{\mathrm{i}}$ channels (Grudt and Williams, 1993) or closing $\mathrm{Ca}^{2}$ channels (Gross and MacDonald, 1987; Bean, 1989). We have recently found that dynorphin acts directly on NMDA receptors without the involvement of opioid receptors (Chen and Huang, 1992b, 1993; Chen et al., 1995). To better understand the mechanism of dynorphin action, we further studied the kinetics of dynorphin binding, analyzed the modulation of single NMDA channel activity by dynorphin, and explored the site of action for dynorphin.

\section{Materials and Methods}

Acutely dissociated trigeminal neurons were isolated from 9-16 d old Long Evans rals as previously described (Huang, 1989; Gu and Huang: 1991). In brief, the lower medulla and upper cervical regions of the spinal cord were removed and put in an ice-cold, oxygenated dissecting solution, consisting of $(\mathrm{mm}) \mathrm{NaCl}\left(\mathrm{l}_{2} 20\right), \mathrm{KCl}(10), \mathrm{CaCl}_{2}(1), \mathrm{MgCl}_{2}$ (6), glucose (10), and PIPES (10) $(\mathrm{pH}=7.15)$ (osmolarity $=305-315$ mOsm). The tissue was cut into $300 \mu \mathrm{m}$ thick horyontal slices with a vibratome slicer and incubated in the dissecting solution for 15-30 min at $34.5^{\circ} \mathrm{C}$. The slices were then incubated with $0.75 \mathrm{mg} / \mathrm{ml}$ protease III (Sigma) in the dissecting solution for $10 \mathrm{~min}$ at $34.5^{\circ} \mathrm{C}$. After incubation, the tissue was washed with enzyme-free dissecting solution and stored at room temperature. Prior to an experiment, the spinal trigeminal nuclei in the caudal medulla were isolated from a tissue slice with a scalpel. Neurons were dissociated by triturating the tissue with a serics of fire-polished Pasteur pipettes.

Whold-cell and single-chanel cuments were recorded using the patch clamp technique. The external solution contained (mM) $\mathrm{NaCl}(140), \mathrm{KCl}$ (4). glucose (10), HEPES (10) $(\mathrm{pH}=7.4)$, and $\mathrm{CaCl}_{2}$ (2). Unless otherwise stated, $100 \mu \mathrm{M}$ NMDA and $2 \mu \mathrm{m}$ glycine were used. The internal solution contained (mM) Cs methancsulfonate (125), CsCl (15), glucose (10), BAPTA (11), $\mathrm{CaCl}_{2}(1)$, and HEPES (10) $(\mathrm{pH}=7.2)$. The free intracellular $\mathrm{Ca}^{2-}$ concentration was calculated to be $1.6 \times 10^{\times} \mathrm{M}$. $\mathrm{Mg}-$ ATP $(5 \mathrm{~mm})$, leupeptin $(400 \mu \mathrm{M})$, and GTP $(200 \mu \mathrm{M})$ were added to the internal solution to prevent the rundown. All the chemicals were ultrapure grade. The amino acids and various dynorphins were delivered to the recorded cell using the fast perfusion technique (Gu and Huang. 1991). The solution exchange time was measured from the time taken for the whole-cell kainate currents to reach a new steady state as the extracellular $\mathrm{Na}$ was switched from 140 to $70 \mathrm{~mm}$. The solution ex-
A
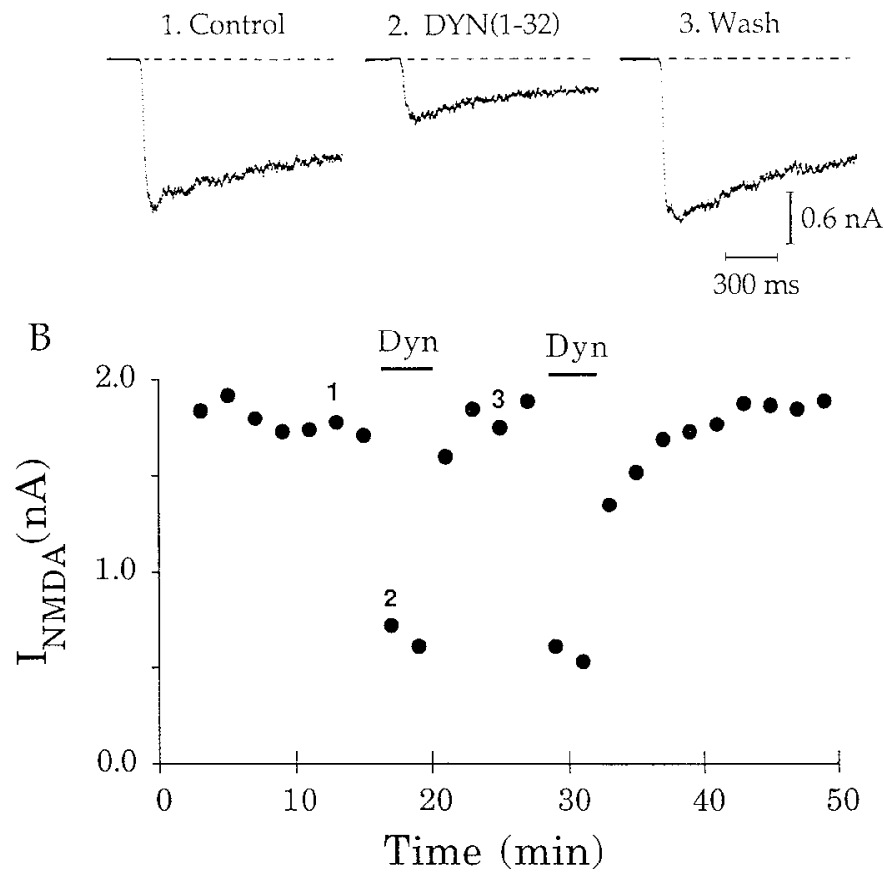

Figure 1. Dynorphin inhibits NMDA-activated currents. A, Dynorphin $(1-32)$, at $0.25 \mu \mathrm{M}$, reduced $I_{\mathrm{N} 1 \mathrm{3}, \mathrm{N}}$ to $40 \%$ of the control. The currents returned to the original amplitude when dynorphin was washed out. B. Time course of dynorphin block. The blocking effect of dynorphin was rapid and the block was reversed after dynorphin was removed from the bath media. The same actions of dynorphin could be repeatedly observed in the same cell. The holding potential was at $-70 \mathrm{mV}$.

change was completed within $10 \mathrm{msec}$. Unless specified, the length of NMDA application was $\sim 12$ sec. To avoid desensitization or rundown of the whole-cell $I_{\text {Nat } 1,}$. NMDA was washer out completely after each application, and NMDA pulses were applied once every 2 min. The least squares method was used to fit the theoretical dose-response curves to the experimental data. The average data values are expressed as mean $\pm \mathrm{SE}$.

Wholc-cell currents were filtered at $2 \mathrm{kH} /$ and sampled at $200 \mu \mathrm{sec}$. Single-channel currents were recorded from outside-oul patches; these signals were filtered at $2 \mathrm{kH} z$ and sampled at $100 \mu \mathrm{sec}$. The amplitude of a single NMDA-activated channel was obtained from amplitude histograms of all the digitized points. Only the main conductance level (37 pS) was included in our analyses. Transition from a closed to an open state was detected when the current level was above $50 \%$ of the main conductance level and lasted longer than twice the filter rise time (Colquhoun and Sigworth, 1983). The idealized trace of each detectable event was superimposed on experimental records for visual inspection. The fraction of time that channels were open was calculated according to the relationship ( $\Sigma$ dwell time $\times$ level no.)/total record time. Opentime distribution which comprises only the duration of single openings were analysed using the binned $(10$ bins/decade) maximum likelihood method (Sigworth and Sine, 1987). The data and fitted curves were expressed as square rool (evernts/bin) versus log (open time).

\section{Results}

Dynorphins, including dynorphin( $1-13),(1-17)$ and (1-32), block the $I_{\mathrm{XM1} \text {, }}$ in the same manner (Chen et al., 1995). These dynorphins reduce $I_{\triangle \mathrm{MD} \text { A }}$ reversibly and the inhibitory action can not be blocked by the opioid antagonist, naloxone, or by the k-opioid antagonist, nor-BNI (Chen et al., 1995). An example of the time course of dynorphin(1-32) action is shown in Figure 1. Dynorphin( $1-32)$ at $0.25 \mu \mathrm{M}$ reduced $I_{\mathrm{N}(1) A}$ by $60 \%$ in this cell. The $I_{X \mathrm{Mi} \text { A }}$ recovered to the control level after the removal of 
A
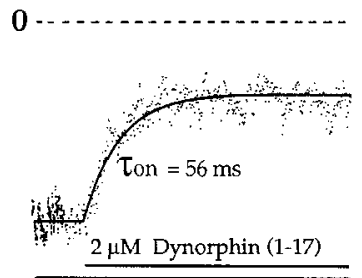

$50 \mu \mathrm{M}$ NMDA

C

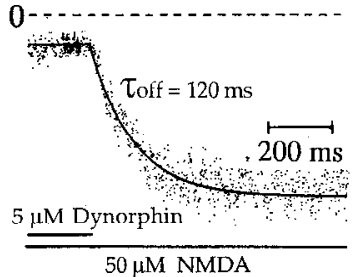

B

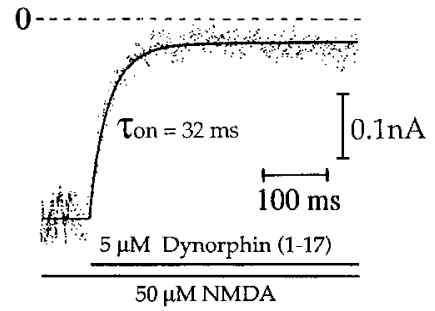

$\mathrm{D}$

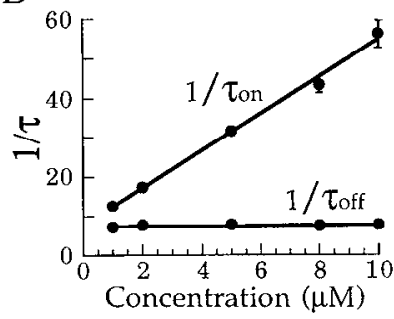

A

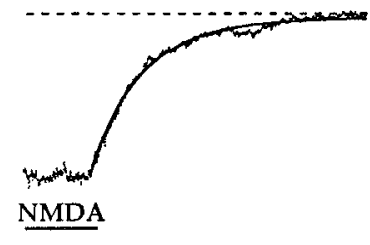

B

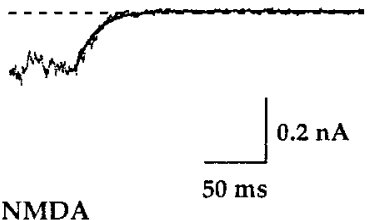

Dynorphin

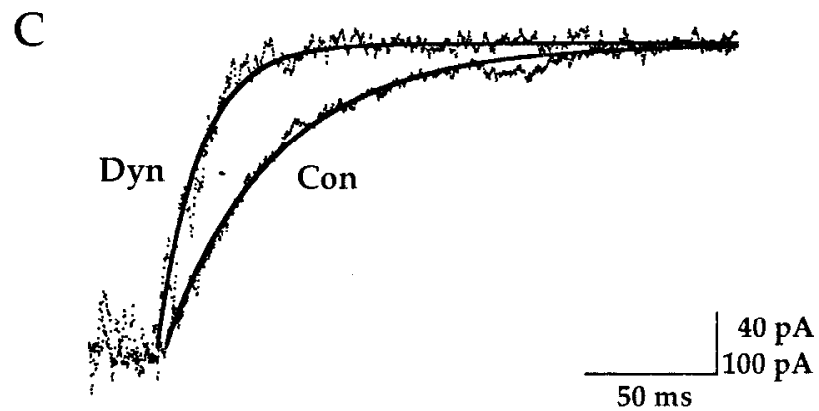

On and off rates of dynorphin(1-17). To obtain the $\tau_{\mathrm{sn}}, I_{\mathrm{NMD} A}$ was recorded during a step application of $2 \mu \mathrm{M}(A)$ and $5 \mu \mathrm{M}$ dynorphin $(B)$ The holding potential was $-70 \mathrm{mV}$. The periods of solution application are indicated by the solid lines below. Lines drawn through the data points are the theoretical fit of single exponential functions. The zero current lines are indicated by dotted lines. $C$, To obtain the $\tau_{\text {off }}$ the NMDA response was recorded during the rapidly washing out of 5 $\mu \mathrm{M}$ dynorphin. $D$, The concentration dependence of $1 / \tau$. The SE values larger than the data points are expressed with bars. The $\tau_{\text {on }}$ values are $1 \mu \mathrm{M}, 79.2 \pm 1.7 \mathrm{msec}(n=6) ; 2 \mu \mathrm{M}, 57.3 \pm 1.8 \mathrm{msec}(n=6) ; 5$ $\mu \mathrm{M}, 31.3 \pm 1.3 \mathrm{mscc}(n=7) ; 8 \mu \mathrm{M}, 23.3 \pm 0.9 \mathrm{msec}(n=6)$; and $10 \mu \mathrm{M}, 17.8 \pm 1.2 \mathrm{msec}(n=4)$. The $1 / \tau_{\text {on }}$ changed linearly with the concentration of dynorphin and $1 / \tau_{\text {off }}$ did not change significantly with dynorphin concentration.

dynorphin from the external solution. The same actions of dynorphin could be repeatedly observed in the same cell (Fig. 1).

The dose-response curves for various dynorphins have been examined in detail (Chen et al., 1995). The affinity of dynorphin(1-32) was the highest $\left(\mathrm{IC}_{50}=0.25 \mu \mathrm{M}\right)$. The affinities of dynorphin (1-17) $\left(\mathrm{IC}_{50}=1.6 \mu \mathrm{M}\right)$ and of dynorphin (1-13) $\left(\mathrm{IC}_{50}\right.$ $=1.8 \mu \mathrm{M})$ were similar. The kinetics of the dynorphin(1-17) block were determined using concentration jump experiments (Fig. 2). After the NMDA responses reached a steady state, the external solution was rapidly switched to a solution containing both NMDA and dynorphin (Fig. $2 A, B$ ). The decrease in $I_{\text {NMDA }}$ was well-fitted by a single exponential; the time constant $\left(\tau_{\text {on }}\right)$ of the binding of dynorphin at $2 \mu \mathrm{M}$ was $57.3 \pm 1.8 \mathrm{msec}(n$ $=6)$ and at $5 \mu \mathrm{M}$ was $31.3 \pm 1.3 \mathrm{msec}(n=6)$. The time constant of the unbinding of dynorphin $\left(\tau_{\text {off }}\right)$ was determined as dynorphin was rapidly washed out (Fig. $2 C$ ). The $\tau_{\text {off }}$ at $5 \mu \mathrm{M}$ dynorphin(1-17) was $127.0 \pm 4.9 \mathrm{msec}(n=5)$. The concentration dependence of $1 / \tau$ is shown in Figure $2 D$. The $1 / \tau_{\text {on }}$ changed linearly with the concentration of dynorphin. According to a one binding site model, $1 / \tau_{\text {on }}=k_{+}$[Dyn $]+k_{-}$and $1 / \tau_{\text {orf }}=$ $k_{-}$where $k_{+}$is the association and $k_{-}$the dissociation rate constants of dynorphin, and [Dyn] is the dynorphin concentration. The $k_{+}$obtained from the slope of the curve was $4.9 \times 10^{6} \mathrm{scc}^{-1}$ $\mathrm{M}^{-1}$. The $\mathrm{y}$-intercept of the curve corresponding to $k_{-}$was 7.5 $\sec ^{-1}$. In contrast, $1 / \tau_{\text {off }}$ did not change significantly with dynorphin concentration (Fig. $2 D$ ). The average $1 / \tau_{\text {off }}$ (i.e., $k_{-}$) obtained from the five concentrations of dynorphin we tested was $k_{-}=7.6 \mathrm{sec}^{-1}$, a value consistent with $k_{-}$obtained from the $1 / \tau_{\text {on }}$ curve. The dissociation constant of dynorphin $\left(K_{D}\right)$ calcu-

Figure 3. Dynorphin speeds up the deactivation of NMDA responses. $A, I_{\text {NMD }}$ recorded after the removal of NMDA from the external solution. The $I_{\text {NMDA }}$ was fitted with a double-exponential function. The time constants of the exponentials are $48.0 \mathrm{msec}$ and $338.6 \mathrm{msec}$. The period of solution application is indicated by the solid line below the trace. The zero current line is indicated by a dotted line. The theoretical curve was drawn through the data points. $B$, In the presence of $2 \mu \mathrm{M}$ dynorphin (1-17), the decay of $I_{\mathrm{NMDA}}$ was fitted with a single-exponential function. The time constant is $16.1 \mathrm{msec}$. $C$, For better comparison, the two current traces were scaled to show the time constant differences. The holding potential was $-70 \mathrm{mV}$.

lated from on and off rates, that is, $K_{D}=k_{-} / k_{+}$, is $1.6 \mu \mathrm{M}$. This value is the same as the apparent dissociation constants $\left(\mathrm{IC}_{50}\right)$ of dynorphin(1-17) obtained from the dose-response experiments (Chen et al., 1995). The recovery from the dynorphin (132) block occurred much slower than $\tau_{\text {off }}$ for dynorphin(1-17) (Fig. 1). This is consistent with fact that the affinity of dynorphin(1-32) is about seven times that of dynorphin (1-17)

Since the decay of the NMDA component of excitatory postsynaptic currents (EPSCs) is governed mainly by the deactivation of NMDA receptor channels (Lester et al., 1990; Pan et al., 1993; Jonas and Spruston, 1994), the dynorphin effect on the deactivation can provide clues as to whether dynorphin could change the time course of EPSC. The deactivation of NMDA responses in control and in dynorphin (1-17) $(2 \mu \mathrm{M})$ was studied. When the external solution was rapidly switched from an NMDA-containing to an NMDA-free solution, the $I_{\text {NMDA }}$ decayed. The decay constants, obtained by fitting the decrease in $I_{\text {NMDA }}$ with a double exponential function, were $50 \pm 2.8 \mathrm{msec}$ and $428 \pm 128 \mathrm{msec}(n=2)$ (Fig. $3 A)$. In the presence of dynorphin, the decay of $I_{\mathrm{NMDA}}$ could be fitted with a single exponential function; the decay time constant became $18.4 \pm 3.3$ msec $(n=2)$. Thus, dynorphin, if released near NMDA receptors, would shorten EPSC, in addition to decreasing its amplitude.

Dynorphins could inhibit NMDA responses by reducing the affinity of NMDA for its recognition site, by changing the binding of glycine or by altering the properties of NMDA receptor channels. To test each of these possibilities, we first determined the dose-response curves for NMDA with and without dynor- 


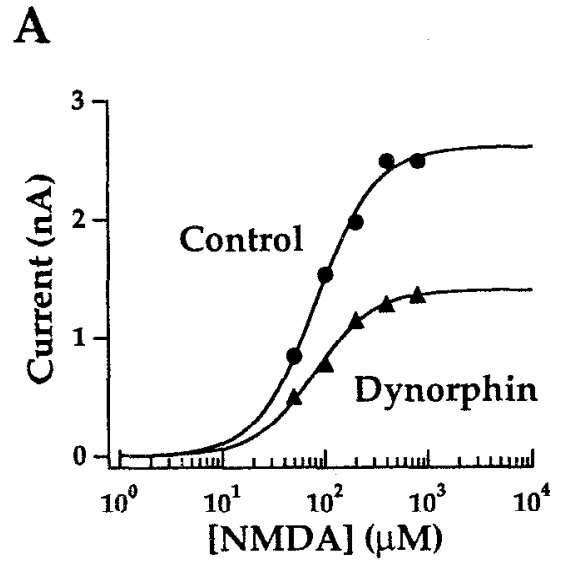

B

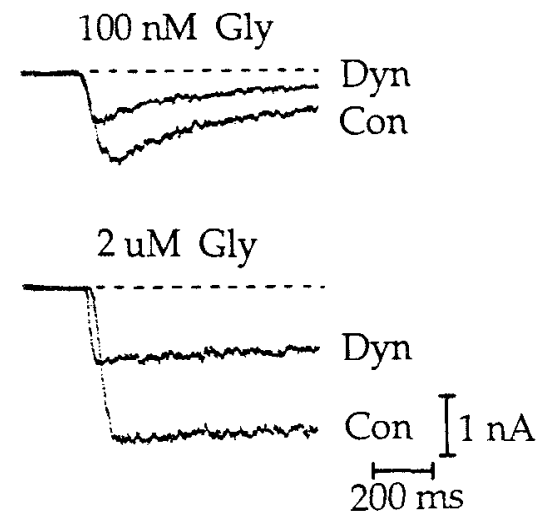

Figure 4. Dynorphin does not act at the NMDA recognition site. A, Dose-response curves for NMDA in the control and in $0.25 \mu \mathrm{M} \mathrm{dy}$ norphin(1-32) solutions. Solid lines were drawn according to the equa tion $I=I_{o}[\mathrm{NMDA}]^{h} /\left(\left[\mathrm{EC}_{50}\right]^{h}+[\mathrm{NMDA}]^{h}\right) . I_{o}$ is the maximal current in the control solution, [NMDA] is the concentration of NMDA, and $h$ is the Hill coefficient. The $\mathrm{EC}_{50}$ for NMDA was $82.5 \mu \mathrm{M}$ in control and $78.5 \mu \mathrm{M}$ in dynorphin. The data are from the same cell. $B$. Effect of dynorphin in different concentrations of glycine solutions. Dynorphin(132) at $0.25 \mu \mathrm{M}$ blocked the $I_{\mathrm{NMDA}}$ by $50 \%$ in the $100 \mathrm{nM}$ glycine and by $53 \%$ in $2 \mu \mathrm{M}$ glycine.

phin. The $\mathrm{EC}_{50}$ for NMD $\Lambda$ obtained from fitting the data with the Hill equation (Fig. 4A) was $68.5 \pm 9.2(n=7)$ in control and $73.3 \pm 17.9(n=3)$ in $0.25 \mu \mathrm{M}$ dynorphin( $1-32)$. The change in the $\mathrm{EC}_{50}$ was not statistically significant $(p>0.5$, Student's $t$ test). We further found that the extent of the dynorphin block of $I_{\text {NMDA }}$ remained unchanged in different concentrations of external glycine (Fig. $4 B$ ). Thus, dynorphin is a noncompetitive blocker at the NMDA and at the glycine binding sites.

Unlike $\mathrm{Mg}^{2+}$, dynorphin blocks NMD $\Lambda$ responses equally well at various membrane potentials (Chen et al., 1995). Proton $\left(\mathrm{H}^{+}\right)$also inhibits NMDA responses in a voltage-independent manner (Tang et al., 1990; Traynelis and Cull-Candy, 1990; Vyklicky et al., 1990; Traynelis and Cull-Candy, 1991). To test whether dynorphin interacts at the $\mathrm{H}^{+}$site, we obtained the dose-response relationship for dynorphin at $\mathrm{pH} 7.4(0.04 \mu \mathrm{M}$ $\left.\left[\mathrm{H}^{\prime}\right]\right)$ and $6.7\left(0.2 \mu \mathrm{M}\left[\mathrm{H}^{+}\right]\right)$. The NMDA responses were decreased at the low $\mathrm{pH}$ (Fig. 5A), similar to those reported previously. However, the $\mathrm{IC}_{50}$ of dynorphin was not altered with a fivefold increase in $\mathrm{H}^{+}$concentration (Fig. $5 B$ ). Thus, it is un-
A
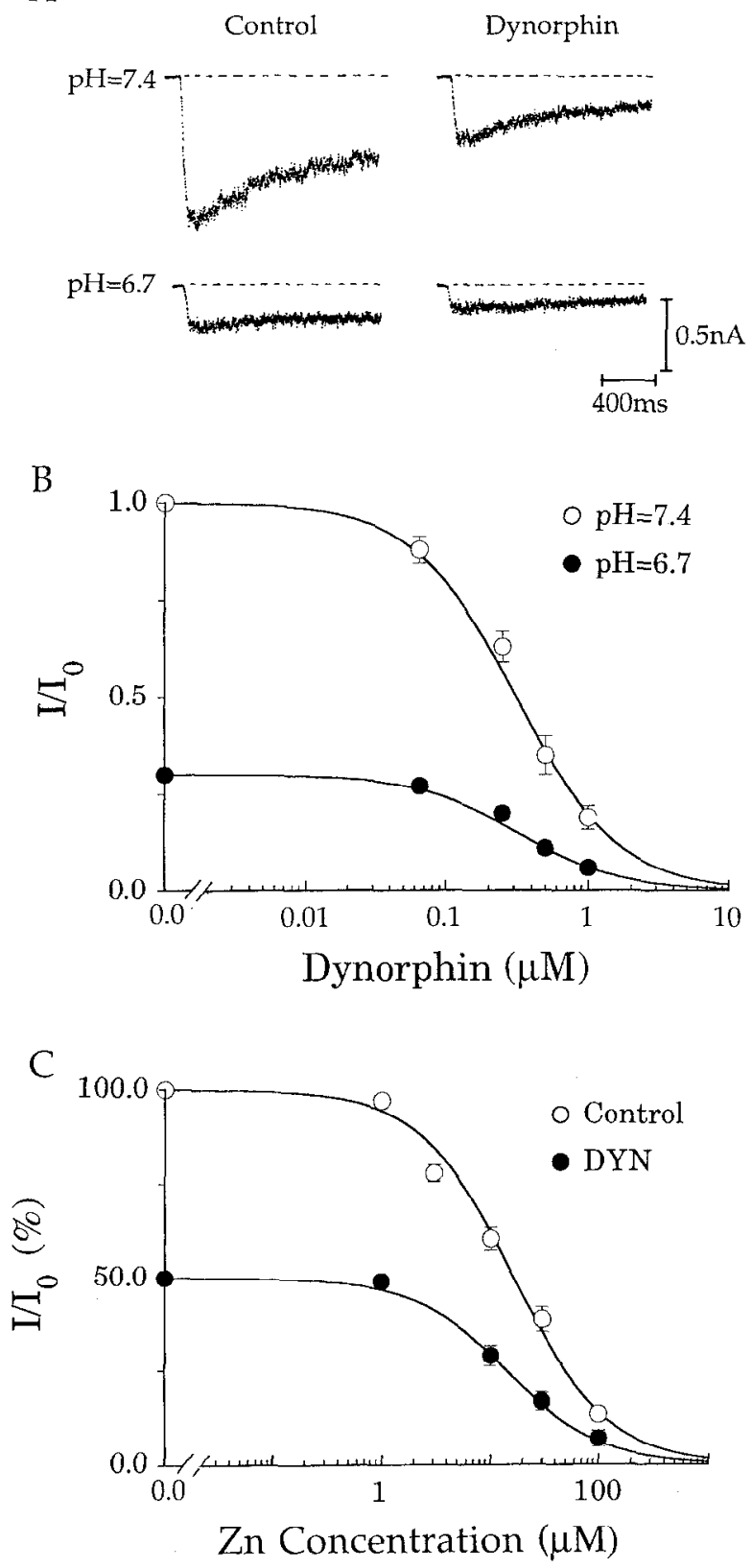

Figure 5. Interaction of dynorphin with $\mathrm{H}^{+}$and $\mathrm{Zn}^{2+}$. A, The NMDA activated currents were reduced by $72 \%$ as the $\mathrm{pH}$ decreased from 7.4 to $6.7\left(\left[\mathrm{H}^{+}\right]\right.$increased from 0.04 to $\left.0.2 \mu \mathrm{M}\right)$. Dynorphin(1-32), at 0.25 $\mu \mathrm{M}$, inhibited NMDA currents by a similar extent at the two pHs. $B$, The dose-response curves of the dynorphin(1-32) block were recorded at $\mathrm{pH}=7.4$ and 6.7. The solid lines were drawn using a equation $I=$

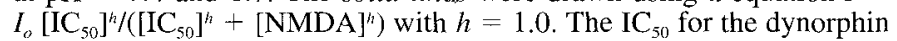
block was $0.31 \mu \mathrm{M}$ at $\mathrm{pH}=7.4$ and $0.32 \mu \mathrm{M}$ at 6.7. Data were average values from six cells. $C$, The dose-response curves of the $\mathrm{Zn}^{2+}$ block were recorded in the control and in $0.25 \mu \mathrm{M}$ dynorphin(1-32). Data were average values from 10 cells. The solid lines were drawn using a similar equation as in $B$ with $h=1.0$. The $I_{50}$ for the $\mathrm{Zn}^{2+}$ block was 16.3 $\mu \mathrm{M}$ in the control and $14.1 \mu \mathrm{M}$ in the dynorphin(1-32).

likely that dynorphin binds to the same site as $\mathrm{H}^{+} . \mathrm{Zn}^{2+}$ was found to be released in synaptic clefts (Assaf and Chung, 1984; Howell et al., 1984) and to potently block $I_{\mathrm{NMDA}}$ in a noncompetitive and relatively voltage-independent manner (Peters et al., 1987; Westbrook and Mayer, 1987). Dynorphin did not appear 


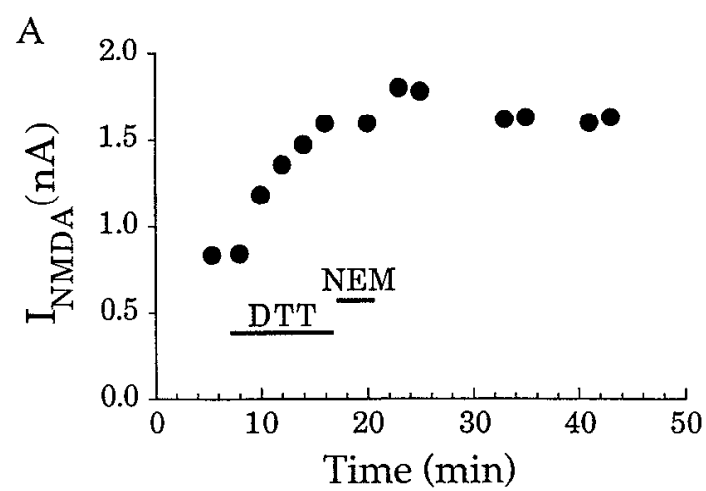

B

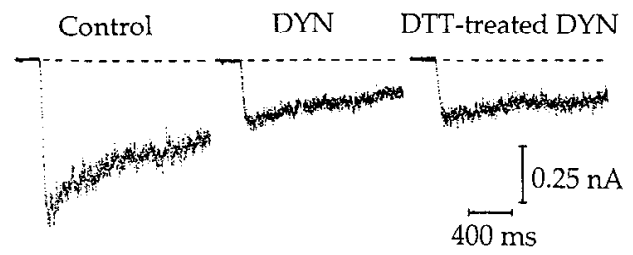

C
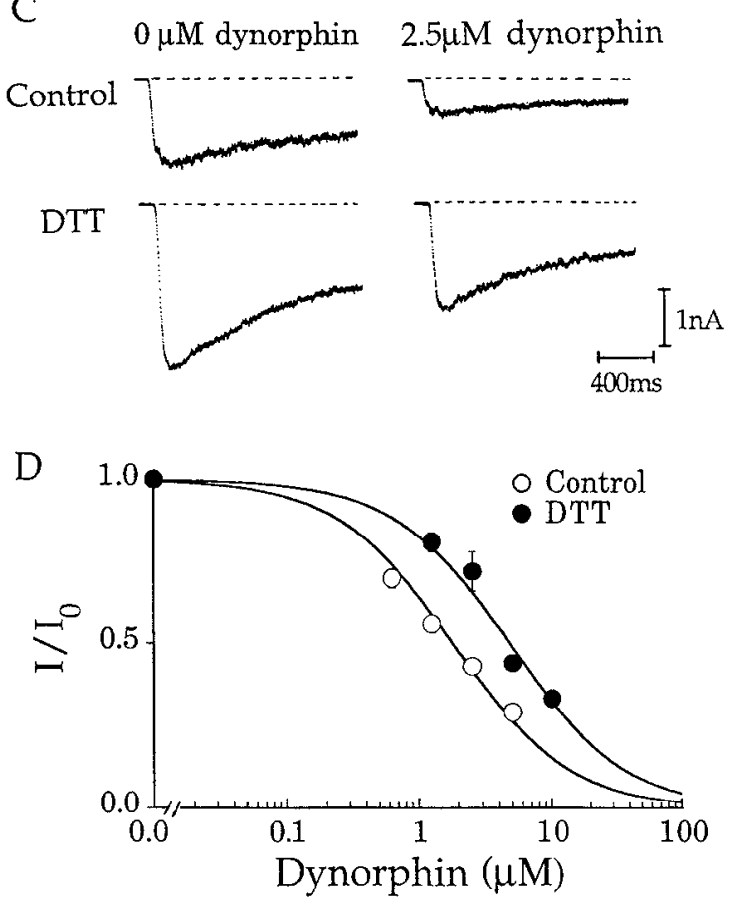

Figure 6. A, The effects of DTT and NEM on NMDA responses. The peak $I_{\text {NMIA }}$ was recorded at every 2 min interval. The bars indicate the time periods when the cell was treated with $3 \mathrm{mM}$ DTT or $1 \mathrm{~mm}$ NEM. The inward $I_{\text {NMvn }}$ was slowly increased during DTT application. The NMDA responses remained elevated when NEM was perfused onto the cell immediately after DTT was washed away. $B$, DTT-treated dynorphin blocked NMDA responses equally well. Dynorphin was preincubated in $3 \mathrm{~mm}$ DTT solution for 10 min before being applied to the cell. There was no difference in the exlent of inhibition of $I_{\mathrm{NMDA}}$ by dynorphin and DTT-treated dynorphin. $C$, Effect of DTT on the affinity of dynorphin(113) for NMDA receptors. The dynorphin block of NMDA responses was reduced in DTT-treated cells. Upper, In the absence of DTT, dynorphin reduced $I_{\mathrm{NMDA}}$ by $57 \%$. Following treatment with $3 \mathrm{mM}$ DTT, NMDA responses were increased. Under this condition, dynorphin reduced $I_{\mathrm{NMDA}}$ by $27 \%$. The data were obtained from the same cell. The membrane potential was held at $-70 \mathrm{mV}$. Lower, The dose-response curves of the dynorphin block before and after DTT treatment. The data are expressed as mean \pm SE for three to eight cells at each dynorphin concentration. The solid lines are the theoretical fit of the average NMDA responses. The $\mathrm{IC}_{5_{0}}$ of dynorphin was $1.8 \mu \mathrm{M}$ in control and was 4.8 in DTT-treated cells.

to bind to the same site as $\mathrm{Zn}^{2+}$ because the $\mathrm{IC}_{50}$ of the dosedependent block of $I_{\mathrm{NMDA}}$ by $\mathrm{Zn}^{2+}$ did not change in the presence of dynorphin (Fig. $5 C$ ).

The sulfhydryl reducing agent, DTT, was found to potentiate the NMDA responses and to modify the properties of NMDA receptor channels (Aizenman et al., 1989; Lazarewicz et al., 1989; Reynolds et al., 1990; Sucher et al., 1990; Traynelis and Cull-Candy, 1991; Tang and Aizenman, 1993; Kohr et al., 1994). We examined whether dynorphin effects are influenced by the modification of disulfide bonds on the NMDA receptor complex. After treatment with DTT, the amplitude of $I_{\mathrm{NMDA}}$ was increased by twofold in our cells (Fig. 6). The potentiation developed slowly. The onset of potentiation was observed 2 min after cells were incubated in DTT solution and the effect reached its steady-state in $10 \mathrm{~min}$ (Fig. 6A). When DTT was removed from the external solution, the $I_{\mathrm{NMDA}}$ returned to the control level in 6-8 min (data not shown). The potentiating effect of DTT became irreversible when DTT-treated cells were exposed to the alkylation agent $N$-ethylmaleimide (NEM) (Fig. 6A). To ensure that DTT did not alter the properties of dynorphin, we incubated dynorphin first in DTT solution for up to $10 \mathrm{~min}$ and then per fused the DTT and dynorphin mixture onto the cells. Because the onset of the DTT effect on NMDA receptors was slow, we were able to test the action of DTT-treated dynorphin prior to the NMDA responses becoming potentiated. There was no difference in the extent of inhibition of $I_{\mathrm{NMDA}}$ by dynorphin and by DTT-treated dynorphin (Fig. 6B). We then studied the effect of dynorphin in DTT-treated cells. Dynorphin became less effective in blocking the NMDA responses (Fig. $6 \mathrm{C}$ ). The $\mathrm{IC}_{50}$ of dynorphin increased from $1.8 \mu \mathrm{M}$ in control to $4.8 \mu \mathrm{M}$ in DTT-treated cells (Fig. $6 \mathrm{C}$ ). Thus reduction of the disulfide bonds located in the NMDA receptor complex significantly changed the binding of dynorphin.

To examine how dynorphin altered the properties of NMDA receptor channels, the effects of dynorphin(1-17) on single NMDA channels were studied in outside-out patches (Fig. 7). The main conductance level did not change in the presence of $1 \mu \mathrm{M}$ of dynorphin(1-17). The fraction of time channels being open $(F)$ in dynorphin was reduced, thus resulting in a marked decrease in the number of overlapping events (Fig. 7A,B). The NMDA channel activity desensitized and ran down in the continuous presence of the agonist. To find out if the actual decrease was due to the dynorphin block, we measured channel currents in the control solution, during dynorphin $(1 \mu \mathrm{M})$ application and after washing out dynorphin. An example of the changes in $F$ during each of these periods is given in Figure $7 C$. The $F$ ratios, that is, $F$ (dynorphin) $/ F$ (control) or $F$ (recovery) $/ F$ (control), obtained from all the patches are summarized in Figure $7 D$. The $F$ ratio for dynorphin was $36 \pm 4 \%(n=14)$ and for recovery was $64 \pm 9 \%(n=6)$. Taking the decay of channel activity into account, dynorphin at $1 \mu \mathrm{M}$ would reduce channel activities to $56 \%$ of the control, which is consistent with the value $(61 \%)$ obtained in whole-cell experiments (Chen et al., 1995).

To study the effect of dynorphin on the open times of NMDA 
A

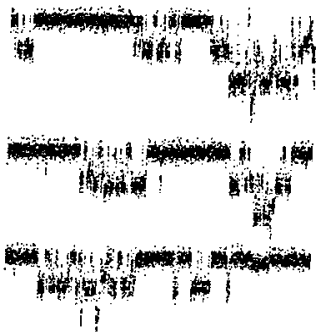

B
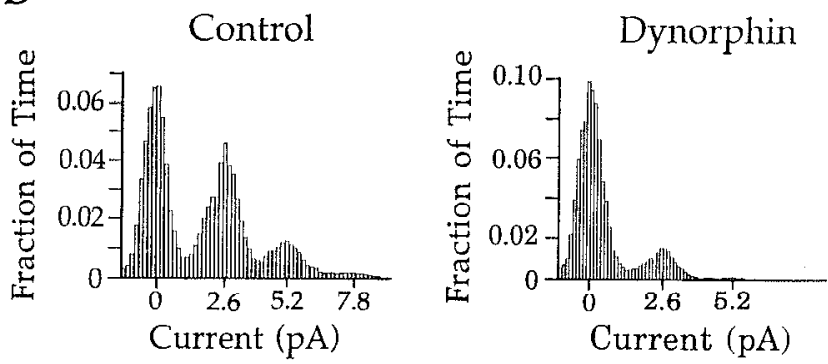

C

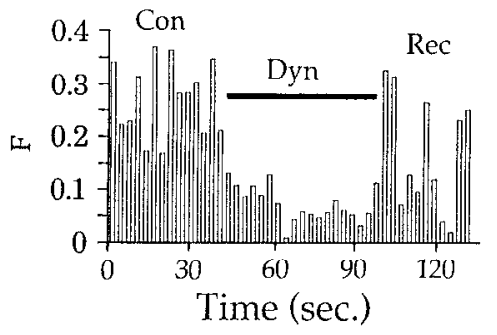

$\mathrm{D}$

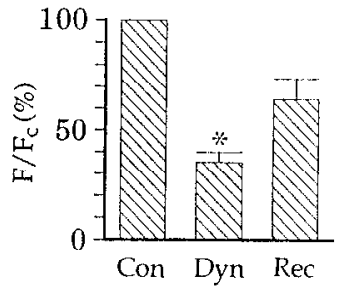

Figure 7. Effect of dynorphin(1-17) on single-channel currents. A, Single-channel currents were recorded from an outside-out patch at -70 $\mathrm{mV}$ before and after dynorphin(1-17) (1 $\mu \mathrm{M})$ treatment. The external solutions contained $10 \mu \mathrm{M}$ NMDA and $2 \mu \mathrm{M}$ glycine. Inward currents appear as downward deflections. $B$, Amplitude histogram obtained from the same patch as shown in $A$. The main current level was $2.6 \mathrm{pA}$ both in the control and in dynorphin. The relative $F$ ratio, that is, $F$ (dynorphin) $/ F$ (control), in this patch was 0.22 . $C$, The recovery of dynorphin effect. An example of the time course of $F$ during the control, the dynorphin application and the washing out of dynorphin is shown. Each bar represents $F$ calculated from a $0.4 \mathrm{sec}$ current record. The period of dynorphin application is indicated by the solid line in the graph. $D$, The $F$ ratio relative to that of the control during dynorphin application and recovery period summarized from all the experiments ( $F$ for control was set at $100 \%)$. The $F$ ratio was $35.6 \pm 4.48 \%(n=$ 14) for dynorphin $(P<0.001, t$ test $)$ and $64.4 \% \pm 9.45 \%(n=6)$ for recovery $(P>0.2)$.

channels, the channel activities in control and in $1 \mu \mathrm{M}$ dynorphin(1-17) were recorded from the same patches (Fig. 8). The open-time histograms of the main conductance state of NMDAactivated channels were fitted by two exponentials. The fast component was changed from $2.1 \pm 1.1 \mathrm{msec}$ in control to 1.4 $\pm 0.2 \mathrm{msec}$ in dynorphin $(n=7)$; the slow component was decreased from $9.7 \pm 0.8 \mathrm{msec}$ to $3.5 \pm 0.6 \mathrm{msec}$. Dynorphin(1-17) reduced the mean open time of NMDA channels by $34 \%(p<0.05, t$ test). Because channels opened infrequently in the presence of dynorphin, very low concentrations of NMDA were not used in the single-channel recordings (Jahr and Ste- vens, 1990; Gibb and Colquhoun, 1992; Lin and Stevens, 1994). Accurate analyses of the closed time could not be obtained with accuracy. Since the decrease of open time was not sufficient to account for the total reduction in whole currents or in $F$, the closed time of the channel might also be lengthened by dynorphin.

\section{Discussion}

Dynorphin reduces NMDA-activated currents without involving opioid receptors (Гig. 1) (Chen et al., 1995). This has led to the suggestion that dynorphin acts directly at the NMDA receptor channels (Chen et al., 1995). We also propose that the dynorphin site is located at the extracellular domain of an NMDA channel because of the large molecular size and the voltage-independent action of dynorphin (Chen et al., 1995). Since dynorphin does not change the $\mathrm{EC}_{50}$ of NMDA, and external glycine has no effect on the dynorphin block of NMDA receptor channels, dynorphin does not interact with the NMDA or glycine recognition sites. The facts that the $\mathrm{IC}_{3}$ of $\mathrm{Zn}^{2+}$ remains the same in the presence of dynorphin and that the $\mathrm{IC}_{50}$ of dynorphin is unchanged with increasing $\mathrm{H}^{+}$concentration also argue against the interaction of dynorphin with the $\mathrm{Zn}^{2+}$ or the $\mathrm{H}^{+}$site. Since the effect of dynorphin persists in cell-free patches, second messenger systems do not appear to play a role in the action of dynorphin.

The dynorphin affinity is substantially lowered when the disulfide bonds in NMDA receptors are reduced by DTT. There are at least two possibilities for this to occur: (1) dynorphin interacts with the redox modulatory site and (2) dynorphin acts at a site conformationally linked with the redox sites on the NMDA receptors. Since dynorphin is not an oxidizing agent and the effect of dynorphin, unlike other oxidizing agents, is decreased with DTT treatment, dynorphin does not appear to act directly on the redox site. Our data are consistent with the second possibility, that is, dynorphin binds to a site which is conformationally altered by the sulfhydryl reducing agent. The information on the molecular composition of the NMDA receptors in trigeminal neurons is not yet available. We do not know the subunits on which these redox sites are located. Nevertheless, the redox sites on NR1-NR2A heteromeric channels have been shown to respond to DTT very differently from those on NR1NR2B, -NR2C, and -NR2D (Kohr et al., 1994). Since the DTT effect in our cells develops slowly and can be made irreversible by the alkylation agent NEM, the redox sites associated with dynorphin are not likely to be on the NR2A subunit. In the spinal dorsal horn, NR1 mRNA is abundantly expressed, with NR2D lightly expressed and with NR2C occasionally found in lamina II neurons (Tolle et al., 1993). NR2A and NR2B mRNA are not detectable (Tolle et al., 1993). Our DTT effects are consistent with the redox sites on the NR1-NR2C or NR1-NR2D subunits. Single-channel analyses indicate that dynorphin reduces the mean open-time of NMDA receptor channels. The decrease in $F$ can account for the reduction in whole-cell currents. Perhaps, dynorphin acts at a site conformationally linked with the redox modulatory site on NR1-NR2C or NR1-NR2D subunits at the extracellular domain of the NMDA receptor channel. In any case, the reduction of dynorphin effect after the DTT modification of NMDA receptor channels further supports our contention that dynorphin acts directly on NMDA receptors, thus altering the conformation of channel protein and thereby changing the gating property of the channel.

At first glance, the apparent dissociation constants of dynor- 

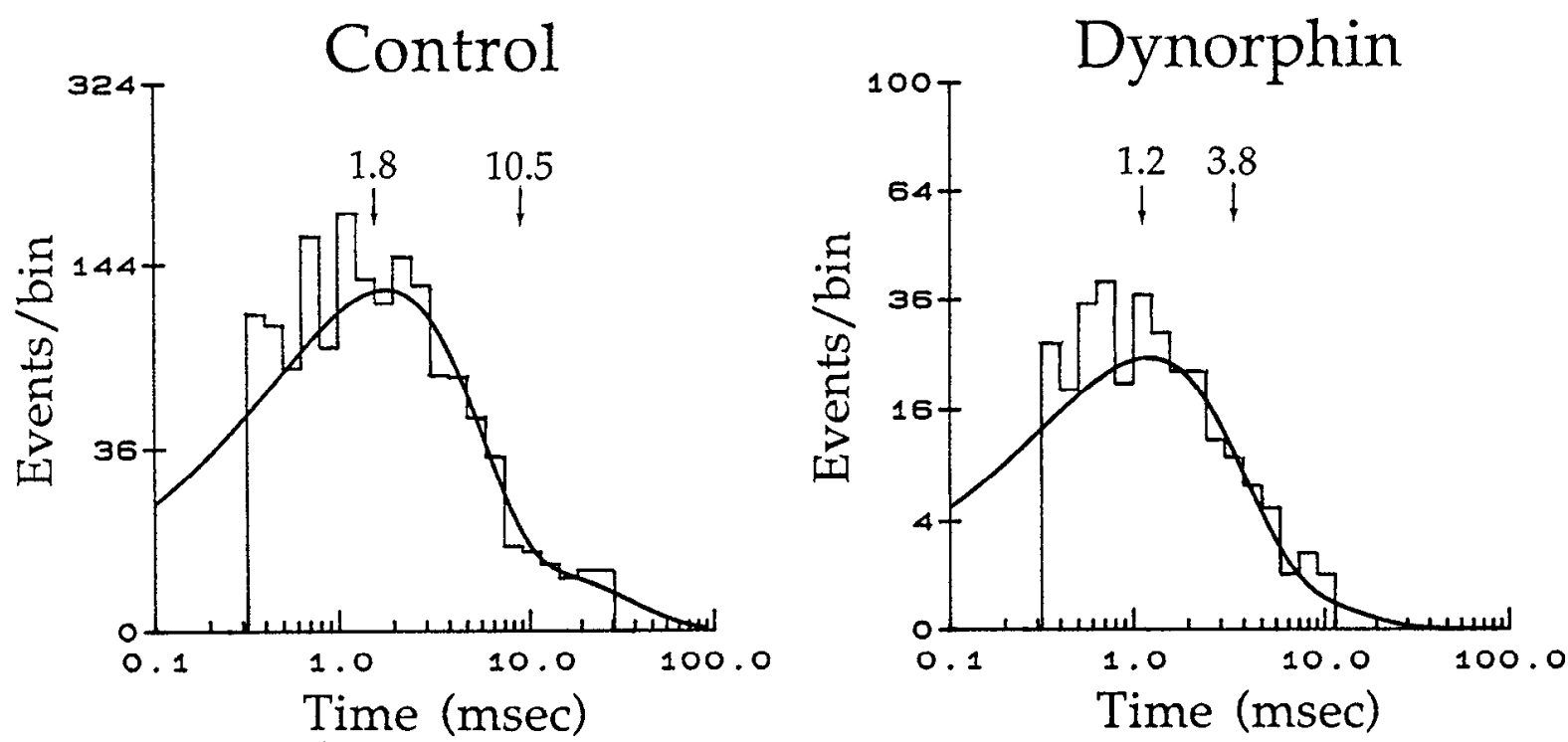

Figure 8. Open-time histograms in control and in $1 \mu \mathrm{M}$ dynorphin(1-17). The open-time distributions for NMDA receptor channels were binned logarithmically. The events/bin is expressed as a square root scale. The histograms were fitted by the sum of two exponentials (continuous line). The time constants were indicated by arrows. The mean open times in control were 1.8 and $10.5 \mathrm{msec}$; the relative areas associated with the two exponentials were 0.97 and 0.03 . The mean open times in dynorphin were 1.2 and $3.8 \mathrm{msec}$; the relative areas associated with each exponential were 0.98 and 0.02 .

phin for NMDA receptors seem rather high, considering the dynorphin level in wet tissue is $30-50 \mathrm{~nm}$ in the brain and in the spinal cord (Millan et al., 1986). However, the action of a transmitter is determined by its concentration in the synaptic cleft, which is usually several orders of magnitude higher than that in the extracellular space. For example, glutamate concentration was estimated to be $100 \mathrm{~mm}$ in the synaptic vesicle (Nicholls and Attwell, 1990; Kanai et al., 1993), $1 \mathrm{~mm}$ at the postsynaptic membrane (Clements et al., 1992) and $1 \mu \mathrm{M}$ in the extracellular space (Nicholls and Attwell, 1990; Kanai et al., 1993). Various forms of enkephalins, dynorphins and their precursors were found to release from nerve terminals (Chavkin ct al., 1983; Terrian et al., 1990) or to co-release with catecholamine from chromaffin granules and dense cored vesicles of the sympathetic nerve (Wilson et al., 1980; Dumont et al., 1983; Rossier et al., 1984). The estimated concentration of enkephalin in the vesicles was between 0.4 and $1.8 \mathrm{~mm}$ (Viveros et al., 1979; Wilson et al., 1980; Winkler and Wethead, 1980; Klein et al., 1982). The dynorphin content was seven to eight times less than the enkephalin content (Klein and Thureson-Klein, 1984; Millan et al., 1986). Assuming the average width of excitatory synapses to be $20 \mathrm{~nm}$ and the diameter of synapses to be around $2 \mu \mathrm{m}$ (Eccles and Jaeger, 1958), the simple diffusion model predicts that the concentration of dynorphin at the NMDA receptor in the postsynaptic membrane would reach tens of $\mu \mathrm{M}$, a value within the range observed for $\mathrm{IC}_{50}$ of dynorphin. Furthermore, the dynorphin level increases two- to fourfold with tissue injury. Thus, under physiological and pathological conditions, dynorphin re leased in response to high frequency stimulation in the vicinity of synaptic clefts would reach a sufficiently high concentration to affect the activity of NMDA receptor channels.

The direct block of NMDA responses may well be a general action of dynorphin, since the same dynorphin effect has been observed in isolated periaqueductal gray neurons (Lai and Huang, unpublished observations). If dynorphin-containing terminals can modulate neuronal activity without the involvement of opioid receptors, this may explain the prevalence of the naloxone-insensitive actions of dynorphin (Moise and Walker, 1985; Faden, 1990; Dubner and Ruda, 1992; Caudle et al., 1994) and the mismatch between the distribution of opioid receptors and opioid-containing terminals (Mansour et al., 1988).

Since dynorphin reduces glutamate release (Wagner et al., 1993; Weisskopf et al., 1993) and blocks NMDA responses (Fig. 1; Chen et al., 1995), the net effect of dynorphin at NMDA receptors is inhibitory. Therefore, dynorphin can not sensitize nociceptive projection neurons by direct interaction on NMDA receptors as previously proposed (Dubner and Ruda, 1992). However, this does not exclude the possibility that dynorphin exerts excitatory action on projection neurons through a disinhibition mechanism(s) (Zieglgansberger and Tulloch, 1979; Madison and Nicoll, 1988). This could occur when dynorphin reduces the activity of GABA- or glycine-containing interneurons, resulting in an overall loss of inhibitory control of the projection neurons. The dynorphin action described here may also be important in modulating neuronal activity in other regions of the brain. For instance, in the CA3 hippocampus, one of the effects of dynorphin(1-17), which is not opioid receptor mediated, is to enhance NMDA synaptic currents (Caudle et al., 1994). Although the functional role of this dynorphin effect has yet to be elucidated, it would be interesting to determine whether disinhibition also plays a role in this dynorphin action and if dynorphin contributes to the development of activity-dependent neuronal plasticity such as long term potentiation (Ben-Ari et al., 1992; Bliss and Collingridge, 1993) in hippocampal neurons.

\section{References}

Aanonsen LM, Wilcox GL (1987) Nociceptive action of excitatory amino acids in the mouse: effects of spinally administered opioids, phencyclidine and $\sigma$ agonists. J Pharmacol Exp Ther 243:9-19.

Aizenman E, Lipton SA, Loring RE (1989) Selective modulation of NMDA responses by reduction and oxidation. Neuron 2:1257-1263. Assaf SY, Chung S-H (1984) Release of endogenous $\mathrm{Zn}^{2+}$ from brain tissue during activity. Nature 308:734-736. 
Battaglia G, Rustioni A (1988) Coexistence of glutamate and substance $\mathrm{P}$ in dorsal root ganglion neurons of the rat and monkey. $\mathbf{J}$ Comp Neurol 277:302-312.

Bean BP (1989) Neurotransmitter inhibition of neuronal calcium currents by changes in channel voltage dependence. Nature 340:153156.

Ben-Ari Y, Aniksztejn L, Bregestovski P (1992) Protein kinase C modulation of NMDA currents: an important link for LTP induction. Trends Neurosci 15:333-339

Besse D, Weil-Fugazza J, Lombard MC, Butler SH, MBJ (1992) Monoarthritis induces complex changes in mu-, delta- and kappa-opioid binding sites in the superficial dorsal horn of the rat spinal cord. Eur J Pharmacol 223:123-131.

Bliss TVP, Collingridge GL (1993) A synaptic model of memory: longterm potentiation in hippocampus. Nature 361:31-39.

Carlton SM, Westlund KN, Zhang D, Willis WD (1992) GABA-immunoreactive terminals synapse on primate spinothalamic tract cells. J Comp Neurol 322:528-537.

Caudle RM, Isaac L (1988) Influence of dynorphin (1-13) on spinal reflexes in the rat. J Pharmacol Exp Ther 246:508-513.

Caudle RM, Chavkin C, Dubner R (1994) к2 opioid receptors inhibit NMDA receptor-mediated synaptic currents in guinea pig CA3 pyramidal cells. J Neurosci 14:5580-5589.

Cesselin F, Montastrue JL, Gross G, Bourgoin S, Hamon M (1980) Met-enkephalin levels and opiate receptors in the spinal cord of chronic suffering rats. Brain Res 191:289-293.

Chavkin C, Bakhit C, Weber E, Bloom FE (1983) Relative contents and concomitant release of prodynorphin/neoendorphin-derived peptides in rat hippocampus. Proc Natl Acad Sci USA 80:7669-16/3.

Chen L, Huang L-YM (1992a) Protein kinase C reduces $\mathrm{Mg}^{2+}$ block of NMDA-receptor channels as a mechanism of modulation. Nature $356: 521-523$.

Chen L, Huang L-YM (1992b) Dynorphin reduces NMDA-activated currents. Soc Neurosci Abstr 18:1502.

Chen L, Huang L-YM (1993) Dynorphin actions on NMDA-activated currents in trigeminal neurons-a single channel analysis. Soc Neurosci Abstr 19:1157.

Chen L, Gu Y, Huang L-YM (1995) Opioid peptide dynorphin directly blocks NMDA-receptor channels. J Physiol (Lond) 482:575-581.

Clements JD, Lester RAJ, Tong G, Jahr CE, Westbrook GL (1992) The time course of glutamate in the synaptic cleft. Science 258:1-1501.

Colquhoun D, Sigworth FJ (1983) Fitting and statistical analysis of single channel records. In: Single-channel recording (Sakmann B, Neher E, eds), pp 191-263. New York: Plenum.

Cone RI, Weher F, Barchas JD, Goldstein A (1983) Regional distribution of dynorphin and neo-endorphin peptides in rat brain, spinal cord, and pituitary. J Neurosci 3:2146-2152.

Cruz L, Basbaum AI (1985) Multiple opioid peptides and the modulation of pain: immunohistochemical analysis of dynorphin and enkephalin in the trigeminal nucleus caudalis and spinal cord of the cat. J Comp Neurol 240:331-348.

Davies SN, Lodge D (1987) Evidence for involvement of $N$-methyl$D$-aspartate receptors in 'wind-up' of class 2 neurones in the dorsal horn of the rat. Brain Res 424:402-406.

Delay-Goyet P, Kayser V, Zajac JM, Guilbaud G, Besson JM, Rogues BP (1989) Lack of significant changes in $\mu$ and $\delta$ binding sites and neutral endopeptidase EC 3.4.24.11 in the brain and spinal cord of arthritic rats. Neuropharmacology 28:1341-1348.

Dickenson AH, Sullivan AF (1987) Evidence for a role of the NMDA receptor in the frequency dependent potentiation of deep dorsal horn neurones following C-fibre stimulation. Neuropharmacology 26: $1235-1238$

Dougherty PM. Willis WD (1992) Enhanced responses of spinothalamic tract neurons to excitatory amino acids accompany capsaicininduced sensitization in the monkey. J Neurosci 12:883-894.

Dougherty PM, Palecek J, Paleckova V, Sorkin LS, Willis WD (1992) The role of NMDA and non-NMDA excitatory amino acid receptors in the excitation of primate spinothalamic tract neurons by mechanical, thermal chemical and electrical stimuli. J Neurosci 12:30253041 .

Dubner R, Ruda MA (1992) Activity-dependent neuronal plasticity following tissue injury and inflammation. Trends Neurosci 15:96-103.

Dumont M, Day R, Lemaire S (1983) Distinct distribution of immunoreactive dynorphin and leucine enkephalin in various population of isolated adrenal chromaffin cells. Life Sci 32:287-294.
Eccles JC, Jaeger JC (1958) The relationship between the mode of operation and the dimensions of the junctional regions at synapses and motor end-organs. Proc R Soc Lond [Biol] 148:38-58.

Faden AI (1990) Opioid and non-opioid mechanism may contribute to dynorphin's pathophysiologic action in spinal cord injury. Ann Neurol 27:67-74.

Fields HL (1987) Painful dysfunction of the nervous system. In: Pain, pp 133-169. New York: McGraw-Hill.

Fleetwood-Walker SM, Hope PJ, Mitchell R, El-Yassir N, Molony V (1988) The influence of opioid receptor subtypes on the processing of nociceptive inputs in the spinal dorsal horn of the cat. Brain Res 151:213-226.

Gannon RL, Terrian DM (1991) U-50,488H inhibits dynorphin and glutamate release from guinea pig hippocampal mossy fiber termiIlals. Brain Res 548:242-247.

Gerber G, Randić M (1989) Excitatory amino acid-mediated components of synaptically evoked input from dorsal roots to deep dorsal horn neurons in the rat spinal cord slice. Neurosci Lett 106:211-219.

Gibb AJ, Colquhoun D (1992) Activation of $N$-methyl-D-aspartate receptors by L-glutamate in cells dissociated from adult rat hippocampus. J Physiol (Lond) 456:143-179.

Gouarderes C, Cros J, Quirion R (1985) Autoradiographic localization of $\mu, \delta$, and $\kappa$ opioid receptor binding sites in rat and guinea pig spinal cord. Neuropeptides 5:331-342.

Gross RA, MacDonald RL (1987) Dynorphin A selectively reduces a large transient (N-type) calcium current of mouse dorsal root ganglion neurons in cell culture. Proc Natl Acad Sci USA 84:5469-5473.

Grudt TJ, Williams JT (1993) к-Opioid receptors also increase potassium conductance. Proc Natl Acad Sci USA 90:11429-11432.

Gu YP, Huang L-YM (1989) Effects of the excitatory amino acids on neurons isolated from spinal trigeminal nuclei. Soc Neurosci Abstr 15:947.

Gu Y-P, Huang L-YM (1990) The modulation of kainate receptor channels by $\mathrm{Ca}$ ions in isolated trigeminal neurons of rat. Soc Neurosci Abstr 16:547

Gu Y, Huang L-YM (1991) Block of kainate receptor channels by $\mathrm{Ca}^{2+}$ in isolated spinal trigeminal neurons of rat. Neuron 6:777-784.

Headley PM, Parsons CG, West DC (1987) The role of $N$-methylaspartate receptors in mediating responses of rat and cat spinal neurones to defined sensory stimuli. J Physiol (Lond) 385:169188.

Herman BH, Goldstein A (1985) Antinociception and paralysis induced by intrathecal dynorphin A. J Pharmacol Exp Ther 232:27-32.

Hope PJ, Fleetwood-Walker SM, Michell R (1990) Distinct antinociceptive actions mediated by different opioid receptors in the region of lamina I and laminae II-V of the dorsal horn of the rat. $\mathrm{Br} \mathbf{J}$ Pharmacol 10:477-483.

Howell GA, Welch MG, Frederickson CJ (1984) Stimulation-induced uptake and release of zinc in hippocampal slices. Nature 308:736738.

Huang L-YM (1989) Calcium channels in isolated rat dorsal horn ncurones including labelled spinothalamic and trigeminothalamic cells. J Physiol (Lond) 41 1:161-177.

Huang L-YM (1995) Cellular mechanisms of excitatory and inhibitory actions of opioids. In: The pharmacology of opioid peptides (Tseng L, ed), in press. Netherlands: Hardwood.

Hutchison WD, Morton CR, Terenius L (1990) Dynorphin A: in vivo release in the spinal cord of the cat. Brain Res 532:299-306.

Hylden JLK, Nahin RI., Traub RI, Dubner R (1991) Effects of spinal kappa-opioid receptor agonists on the responsiveness of nociceptive superficial dorsal horn neurons. Pain 44:187-193.

Iadarola MJ, Douglass J, Civelli O, Naranjo JR (1988) Differential activation of spinal cord dynorphin and enkephalin neurons during hyperalgesia: evidence using cDNA hybridization. Brain Res 455: 205-212.

Jahr CE, Jessell TM (1985) Synaptic transmission between dorsal root ganglion and dorsal horn neurons in culture: antagonism of monosynaptic excitatory postsynaptic potentials and glutamate excitation by kynurenate. J Neurosci 5:2281-2289.

Jahr CE, Stevens CF (1990) A quantitative description of NMDA receptor-channel kinetic behavior. J Neurosci 10:1830-1837.

Jonas P, Spruston N (1994) Mechanisms shaping glutamate-mediated excitatory postsynaptic currents in the CNS. Curr Opinion Neurobiol $4: 366-372$.

Kajander KC, Sahara Y, Iadarola MJ, Bennett GJ (1990) Dynorphin 
increases in the dorsal spinal cord in rats with a painful peripheral neuropathy. Peptides 11:719-728.

Kanai Y, Smith GP, Hediger MA (1993) The elusive transporters with a high affinity for glutamate. Trends Neurosci 16:365-370.

Klein RL, Thureson-Klein AK (1984) Noradrenergic vesicles molecular organization and function. In: Handbook of neurochemistry, $2 \mathrm{~d}$ ed (Lajtha A, ed), pp 71-109. New York: Plenum.

Klein RL, Wilson SP, Dzielak DJ, Yang W-H, Viveros OH (1982) Opioid peptides and noradrenaline co-exist in large dense-cored vesicles from sympathetic nerve. Neuroscience 9:2255-2561.

Knox RJ, Dickenson AH (1987) Effects of selective and non-selective K-opioid receptor agonists on cutaneous $\mathrm{C}$-fibre-evoked responses of rat dorsal horn neurons. Brain Res 415:21-29.

Kohr G, Eckardt S, Luddens H, Monyer H, Seeburg PH (1994) NMDA receptor channels: suburit-specific potentiation by reducing agents. Neuron 12:1031-1040.

Lazarewicz JW, Wroblewski JT, Palmer ME, Costa E (1989) Reduction of disulfide bonds activates NMDA sensitive glutamate receptors in primary cultures of cerebellar granule cells. Neurosci Res Commun 3:91-97.

Lester RA, Clements JD, Westbrook GL, Jahr CE (1990) Channel kinetics determine the time course of NMDA receptor-mediated synaptic currents. Nature 346:565-567.

Lin F, Stevens CF (1994) Both open and closed NMDA receptors desensitize. J Neurosci 14:2153-2160.

Madison DV, Nicoll RA (1988) Enkephalin hyperpolarizes interneurones in the rat hippocampus. J Physiol (Lond) 398:122-130.

Madison DV, Malenka RC, Nicoll RA (1991) Mechanisms underlying long-term potentiation of synaptic transmission. Annu Rev Neurosci $14: 379-397$.

Mansour A, Watson SJ (1993) Anatomical distribution of opioid receptors in mammalians: an overview. In: Opioids I (Hertz A, ed), pp 79-105. Berlin: Springer.

Mansour $\Lambda$, Khachaturian H, Lewis ME, Watson SJ (1988) $\Lambda$ natomy of CNS opioid receptors. Trends Neurosci 11:308-314.

Millan MJ (1989) Kappa-opioid receptor-mediated antinociception in the rat. I. Comparison on mu- and kappa-antinociception against noxious thermal, pressure and electrical stimuli. J Pharmacol Exp Ther 251:334-351.

Millan MJ (1990) к-Opioid receptors and analgesia. Trends Pharmacol Sci 11:70-76.

Millan M.J (1993) Multiple opioid systems and chronic pain. In: Handbook of experimental pharmacology, Vol 104/I, Opioids II (Herz A, ed), pp 127-162. Berlin: Springer.

Millan MJ, Millan MH, Czlonkowski A, Hollt V, Pilcher CWT (1986) A model of chronic pain in the rat: response of multiple opioid systems to adjuvant-induced arthritis. J Neurosci 6:899-906.

Miller K, Seybold VS (1987) Comparison of met-enkephalin-, dynorphin A- and neurotensin-immunoreactive neurons in the cat and rat spinal cords. I. Lumbar cord. J Comp Neurol 255:293-304.

Moise HC, Walker JM (1985) Electrophysiological effects of dynorphin peptides on hippocampal pyramidal cells in rats. Eur J Pharmacol 108:85-98

Morris BJ, Herz A (1987) Distinct distribution of opioid receptor types in rat lumbar spinal cord. Naunyn Schmiedebergs Arch Pharmacol $336: 240-243$

Nahin RL, Hylden JL, Humphrey E (1992) Demonstration of dynorphin A 1-8 immunoreactive axons contacting spinal cord projection neurons in a rat model of peripheral inflammation and hyperalgesia. Brain Res 51:135-143.

Nicholls D, Attwell D (1990) The release and uptake of excitatory amino acids. Trends Pharmacol Sci 11:462-468.

Pan ZZ, Tong G, Jahr CE (1993) A false transmitter at excitatory synapses. Neuron 11:85-91.

Peters S, Koh J, Choi DW (1987) Zinc selectively blocks the action of $N$-methyl-D-aspartate on cortical neurons. Science 236:589-593.

Potashner SJ, Tran PL (1984) Decreased uptake and release of D-aspartate in the guinea pig spinal cord after dorsal root section. J Neurochem 42:1135-1144.

Reynolds IJ, Rush EA, Aizenmen E (1990) Reduction of NMDA receptors with dithiothreitol increases $\left[{ }^{3} \mathrm{H}\right] \mathrm{MK} 801$ binding and NMDAinduced $\mathrm{Ca}^{2+}$ fluxes. Br J Pharmacol 101:178-182.

Rossier J, Foutz AS, Chaminade M (1984) Release of enkephalins and precursors from perfused cat adrenal glands. In: Opioid peptides in the periphery (Fraioli F, Isidori A, Mazzetti M, eds), pp 39-46. Amsterdam: Elsevier.

Ruda MA, Iadarola MJ, Cohen LV, Young WS (1988) In situ hybridization histochemistry and immunocytochemistry reveal an increase in spinal dynorphin biosynthesis in a rat model of peripheral inflammation and hyperalgesia. Proc Natl Acad Sci USA 85:622-626.

Schneider SP, Perl ER (1985) Selective excitation of neurons in the mammalian spinal dorsal horn by aspartate and glutamate in vitro: correlation with location and excitatory input. Brain Res 360:339343

Schneider SP, Perl ER (1988) Comparison of primary afferent and glutamate excitation of neurons in the mammalian spinal dorsal horn. J Neurosci 8:2062-2073

Sigworth FJ, Sine SM (1987) Data transformations for improved display and filling of single-channel dwell time histograms. Biophys J 52:1047-1054

Skilling SR, Smullin DH, Beitz AJ, Larson AA (1988) Extracellular amino acid concentration in dorsal spinal cord of freely moving rats following veratridine and nociceptive simulation. J Neurochem 51: $127-132$.

Spampinato S, Candeletti S (1985) Characterization of dynorphin A-induced antinociception at spinal level. Eur J Pharmacol 110:21-30.

Stevens CW, Kajander KC, Bennett GJ, Seybold VS (1991) Differential regulation of opioid binding sites in rat spinal cord in an experimental model of chronic pain. In: Proceedings of the VIth World Congress on Pain (Bond MR, Charlton JE, Woolf CJ, eds), pp 283-289. Amsterdam: Elsevier.

Suarez-Roca H, Maixner W (1993) Activation of kappa opioid receptors by $\mathrm{U} 50488 \mathrm{H}$ and morphine enhances the release of substance $\mathrm{P}$ from rat trigeminal nucleus slices. J Pharmacol Exp Ther 264:648653.

Sucher NJ, Wong LA, Lipton SA (1990) Redox modulation of NMDA receptor-mediated $\mathrm{Ca}^{2+}$ flux in mammalian central neurons. Neuroreport 1:29-32.

Tang CM, Dichter M, Morad M (1990) Modulation of the $N$-methylD-aspartate channel by extracellular $\mathrm{H}^{+}$. Proc Natl Acad Sci USA 87 : 6445-6449.

Tang L, Aizenman E (1993) The modulation of $N$-methyl-D-aspartate receptors by redox and alkylating reagents in rat cortical neurones in vitro. J Physiol (Lond) 465:303-323.

Terrian DM, Gannon RL, Rea MA (1990) Glutamate is the endogenous amino acid selectively released by rat hippocampal mossy fiber synaptosomes concomitantly with prodynorphin-derived peptides. Neurochem Res 15:1-5.

Tolle TR, Berthele A, Zicglgansberger W, Secburg PH, Wisden W (1993) The differential expression of 16 NMDA and non-NMDA receptor subunits in the rat spinal cord and in periaqueductal gray. $\mathbf{J}$ Neurosci 13:5009-5028.

Traynelis SF, Cull-Candy SG (1990) Proton inhibition of $N$-methyl-Daspartate receptors in cerebellar neurons. Nature 345:347-350.

Traynelis SF, Cull-Candy SG (1991) Pharmacological properties and $\mathrm{H}^{+}$sensitivity of excitatory amino acid receptor channels in rat cerebellar granule neurones. J Physiol (Lond) 433:727-763.

Viveros OH, Diliberto EJ, Hazum E, Chang K-J (1979) Opiate-like materials in the adrenal medulla: evidence for storage and secretion with catecholamine. Mol Pharmacol 16:1101-1108.

Vyklicky L, Vlachová V, Krusek J (1990) The effect of external $\mathrm{pH}$ changes on responses to excitatory amino acids in mouse hippocampal neurones. J Physiol (Lond) 430:497-51\%.

Wagner JJ, Terman GW, Chavkin C (1993) Endogenous dynorphins inhibit excitatory neurotransmission and block LTP induction in the hippocampus. Nature 363:451-454.

Wall PD, Woolf CJ (1984) Muscle but not cutaneous c-afferent input produces prolonged increases in the excitability of the flexion reflex in the rat. J Physiol (Lond) 356:443-458.

Weihe E, Millan MJ, Hollt V, Nohr D, Herz A (1989) Induction of the gene encoding pro-dynorphin by experimentally induced arthritis enhances staining for dynorphin in the spinal cord of rats. Neuroscience 31:77-95

Weisskopf M, Zalutsky RA, Nicoll RA (1993) The opioid peptide dynorphin mediates heterosynaptic depression of hippocampal mossy fibre synapses and modulates long-term potentiation. Nature 362: $423-427$

Werling LL, Brown SR, Cox BM (1987) Opioid receptor regulation of 
the reledse of norepinephrine in brain. Neuropharmacology 26:987996.

Westbrook GL, Mayer ML (1987) Micromolar concentrate of $\mathrm{Zn}^{2+}$ antagonizes NMDA and GABA responses of hippocampal neurons. Nature 328:640-643.

Westlund KN, Carlton SMZ, Willis WD (1992) Glutamate-immunoreactive terminals synapse on primate spinothalamic tract cells. J Comp Neurol 322:519-527.

Willcockson WS, Kim J, Shin HK, Chung JM, Willis WD (1986) $\Lambda \mathrm{c}$ tions of opioids on primate spinothalamic tract neurons. J Neurosci 6:2509-2520.

Willis WD, Coggeshall RE (1991) The sensory channels. In: Sensory mechanisms of the spinal cord, 2d ed, pp 436-449. New York: Plenum.

Willis WD, Coggeshall RE (1991) Structure of the dorsal horn. In: Sensory mechanisms of the spinal cord, 2d ed, pp 79-151. New York: Plenum.

Wilson SP, Klein RL, Chang K-J, Gasparis MS, Viveros OH, Yang W-H (1980) Are opioid peptides co-transmitters in noradrenergic vesicles of sympathetic nerves? Nature 288:707-709.

Winkler H, Wethead E (1980) Molecular organization of adrenal chromaffin granules. Neuroscience 5:1803-1823.
Woulr CJ, Thompson SWN (1991) The induction and maintenance of central sensitization is dependent of $N$-methyl-D-aspartic acid receptor activation: implications for the treatment of post-injury pain hypersensitivity states. Pain 44:293-299.

Xu H, Gintzler AR (1989) Opioids can enhance and inhibit the electrically evoked release of methionine-enkephalin. Brain Res 584:3642.

Yaksh TL (1993) The spinal actions of opioids. In: Handbook of experimental pharmacology, Vol 104/II, Opioids II (Herz A, ed), pp 53-90. Berlin: Springer.

Yoshimura M, Jessel TM (1989) Primary afferent evoked synaptic responses and slow potential generation in rat substantia gelatinosa neurons in vitro. J Neurophysiol 62:96-108.

Yoshimura M, Jessell T (1990) Amino acid-mediated EPSPs at primary afferent synapses with substantia gelatinosa neurones in the rat spinal cord. J Physiol (Lond) 430:315-335.

Zieglgansberger W (1986) Central control of nociception. In: Handbook of physiology-the nervous system IV (Mountcastle VB, Bloom FE, Geiger SG, eds), pp 581-645. Baltimore: Williams and Wilkins.

Zieglgansberger W, Tulloch IF (1979) The effects of methionine- and leucine-enkephalin on spinal neurones of the cat. Brain Res 167:137148. 